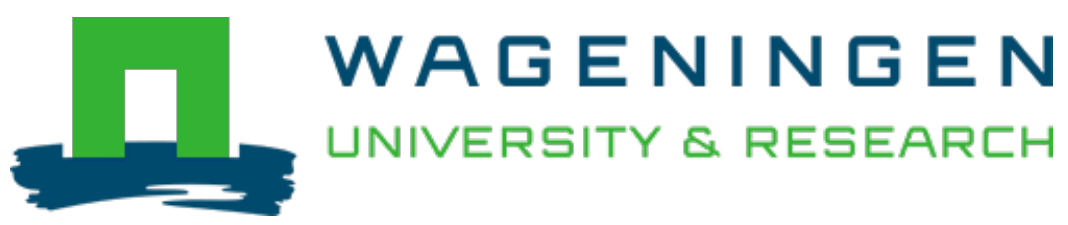

\title{
Building local support for a coastal protected area : Collaborative governance in the Bigi Pan Multiple Use Management Area of Suriname
}

\author{
Marine Policy \\ Djosetro, Marijem; Behagel, Jelle Hendrik \\ https://doi.org/10.1016/j.marpol.2019.103746
}

This article is made publicly available in the institutional repository of Wageningen University and Research, under the terms of article $25 \mathrm{fa}$ of the Dutch Copyright Act, also known as the Amendment Taverne. This has been done with explicit consent by the author.

Article 25 fa states that the author of a short scientific work funded either wholly or partially by Dutch public funds is entitled to make that work publicly available for no consideration following a reasonable period of time after the work was first published, provided that clear reference is made to the source of the first publication of the work.

This publication is distributed under The Association of Universities in the Netherlands (VSNU) 'Article $25 \mathrm{fa}$ implementation' project. In this project research outputs of researchers employed by Dutch Universities that comply with the legal requirements of Article $25 \mathrm{fa}$ of the Dutch Copyright Act are distributed online and free of cost or other barriers in institutional repositories. Research outputs are distributed six months after their first online publication in the original published version and with proper attribution to the source of the original publication.

You are permitted to download and use the publication for personal purposes. All rights remain with the author(s) and / or copyright owner(s) of this work. Any use of the publication or parts of it other than authorised under article $25 \mathrm{fa}$ of the Dutch Copyright act is prohibited. Wageningen University \& Research and the author(s) of this publication shall not be held responsible or liable for any damages resulting from your (re)use of this publication.

For questions regarding the public availability of this article please contact openscience.library@,wur.nl 


\title{
Building local support for a coastal protected area: Collaborative governance in the Bigi Pan Multiple Use Management Area of Suriname
}

\author{
Marijem Djosetro $^{\mathrm{a}, \mathrm{b}, *}$, Jelle Hendrik Behagel ${ }^{\mathrm{b}, * *}$ \\ ${ }^{a}$ Forest Department of the Ministry of Spatial Planning, Land and Forest Management, Suriname \\ ${ }^{\mathrm{b}}$ Forest and Nature Conservation Policy Group (FNP), Wageningen University, the Netherlands
}

\section{A R T I C L E I N F O}

\section{Keywords:}

Marine protected area

Collaborative governance

Multiple use management area

Bigi Pan MUMA

Mangrove

\begin{abstract}
A B S T R A C T
Bigi Pan Multiple Use Management Area (MUMA, IUCN category VI) is a coastal protected area situated in the Northwest Suriname between the Atlantic Ocean and the Nickerie River. The area is characterized by wetlands with mangrove forests, contains high biodiversity, and is of socio-economic, ecological and ornithological importance. However, the MUMA is overexploited and subject to competition between various income generating activities, including uncontrolled fisheries and unregulated tourism combined. Insufficient capacity of government agencies for enforcement and policy implementation and lack of communication between relevant government agencies has further contributed to unsustainable practices that diverge from 'wise use' and conservation. This article analyses the case of Bigi Pan MUMA from the perspective of collaborative governance. It explores how local communities address the conflicts, user pressure, and implementation gaps that lead to unsustainable practices in Bigi Pan MUMA. In addition, it explores the potential of stakeholder engagement with the local community and key user groups to provide meaningful and regular opportunities to actively participate in decision-making structures and to deliberate on management actions. The conclusion finally presents arguments on how collaborative governance can become more effective by including local communities and by strengthening local decision-making and management.
\end{abstract}

\section{Introduction}

The success of marine protected areas strongly depends on the human dimensions and social aspects of nature conservation management [1]. These human dimensions include the presence of strong community leadership [2,3], local support for conservation [4], and conflict management and resolution [1]. In the past, protected areas were often created without the involvement of local communities and user groups [5] and "conservation of biodiversity was mainly sought by establishing protected areas through an exclusive, top-down, government-led process" [6]; p1). Today, the inclusion of local communities in conservation approaches is increasingly promoted to attain more sustainable policies and a more effective and continued policy implementation $[2,3]$.

In the field of marine policy, collaborative governance is a frequently used concept to analyse how local communities and public agencies engage in consensus-oriented decision-making [7]. The purpose of collaboration, according to Emerson et al. [8]; is to generate desired outcomes that could not be accomplished if governance actors acted separate and individually. Emerson et al. [8]; p2) define collaborative governance as: "The processes and structures of public policy decision-making and management that engage people constructively across boundaries of public agencies, levels of government, and/or the public, private and civic spheres in order to carry out public purpose that could not otherwise be accomplished". They highlight that while public agencies are often considered the most likely actor to initiate such cooperation, local communities can equally initiate cooperation.

Local support for protected areas and awareness of environmental impacts of resource use by local communities can result in a more complete conservation approach that includes multiple actors and combines conservation and social objectives [9]. Failure to recognise different resource users and the dependence of local livelihoods on a protected area is also an important reason why many conservation plans remain unimplemented [1,10-12]. Users' compliance with regulation may moreover be eroded by a lack of management capacity [13-15], including insufficient budget to cover all actions of the management

\footnotetext{
* Corresponding author. Trachiet straat no. 15, Maretraite V, Paramaribo, Suriname.

$* *$ Corresponding author. Wageningen Campus, Gebouw 101, Droevendaalsesteeg 3, 6708PB, Wageningen, the Netherlands.

E-mail addresses: marijemdjosetro@gmail.com (M. Djosetro), jelle.behagel@wur.nl (J.H. Behagel).
} 
plan [16], insufficient staff to pursue these actions [16], and a lack of monitoring [17].

The perspectives of local communities on the impacts of their practices and opinions regarding management, policy and environmental outcomes are important for understanding how local support for conservation does or does not take shape $[1,9,18]$. Building trust is moreover key to avoid or manage conflicts between implementation agencies and users, and amongst users themselves [19]. While the complete absence of conflicts may point to exclusion or a lack of meaningful participation [20], visible conflicts over land or marine use themselves usually point to social tensions and negative social interactions [21]. Accordingly, such conflicts can be addressed by attempts to change social interactions, including initiatives that seek to institute collaborative governance.

Most countries in Central America and the Caribbean have limited capacities to govern and manage marine resources [22]. Collaboration between different actor groups is particularly considered a challenge, as many communities lack the capacity to effectively organize and sustainably manage resources. Furthermore, most Marine Protected Areas (MPAs) in the region were established following a top-down approach without including the opinion of the local community directly affected [22]. Today, however, an emerging consensus within the Caribbean Community is that the effective participation of local communities is a fundamental prerequisite for the management of environmental and natural resources [23]. The Bigi Pan coastal protected area in Suriname follows a similar narrative. Bigi Pan consists of wetlands with mangrove forests and is situated in Northwest Suriname, between the Atlantic Ocean and the Nickerie River. Following the establishment of Bigi Pan as a protected area by national government, various conflicts have emerged between local communities and national authorities, competition between resource users is leading to unsustainable use practices, and enforcement of conservation and resource use laws is low. To address these issues, recent efforts towards instituting increased collaboration between various user groups and government agencies have been made.

This article explores how local communities address conflicts, user pressures, and implementation gaps that lead to unsustainable practices in Bigi Pan MUMA. It tests the hypothesis that unsustainable practices can be avoided through collaborative processes, local institutions [4], and by building management capacity $[1,16]$. In addition, it explores the potential of stakeholder engagement with the local community and key user groups to provide meaningful and regular opportunities to actively participate in decision-making structures and to deliberate on management actions [1]. In the remainder of the article, we present our methods and the results of our case study, followed by a discussion of challenges for collaborative governance. We conclude with a reflection on how collaborative governance can become more inclusive of communities in local decision-making and management.

\section{Methods}

\subsection{Analytical framework}

This study follows the model of Ansell and Gash [7] to include four key conditions to account for how collaborative governance does or does not take shape: (1) 'starting conditions', (2) 'institutional design', (3) 'leadership', and (4) ‘collaborative process'. Each condition includes key variables that can positively or negatively influence sustainable governance of natural resources (see Fig. 1). In the study, these conditions were assessed to contribute (a) negatively or not at all, (b) moderately, or (c) positively, via a qualitative interpretation based on conditions described in detail below. In addition, the study applies insights from Ostrom [4] and others on natural resource governance by investigating how different uses of natural resources in the Bigi Pan MUMA relate to policy and local perceptions of user groups.

First, starting conditions refer to the basic levels of trust, conflict and social capital that can either facilitate or discourage cooperation among stakeholders or between government agencies and stakeholders. A prehistory of conflict creates distrust, suspicion, and stereotyping. Alternately, a prehistory of successful cooperation can create social capital and high levels of trust to move the collaborative process forward [7]. Conflicts over natural resources can thus be reduced by collaborative and community-based management approaches [24].

Second, institutional design refers to the basic ground rules for the procedural legitimacy of the collaborative process [7]. These include rules about who should be included in this collaborative process, the organisation of transparency, the formalization of governance structures, the setting of realistic deadlines, and consensus-oriented processes. Ansell and Gash [7] argue that the premise of meeting in a deliberative, multilateral, and formal forum is to strive towards consensus or to discover areas of agreement, even if consensus is not always achieved. Differences in perspectives and knowledge are inputs for the process of deliberation which is important when dealing with problems of multiple and competing objectives [25]. The cultural context and perceived desirability of conservation moreover have considerable influence on conservation outcomes [26,27]9). Analytical focus is therefore on both the formal and on the informal rules that shape behavior [27].

Third, leadership is about the process of bringing stakeholders together and getting them to engage with each other in a collective decision-making process, to set and maintain clear grounds rules, and to provide essential mediation and facilitation for the collaborative process [7]. Leadership is referred to as an essential driver by Emerson et al. [8] to initiate collaborative governance processes. While leadership is

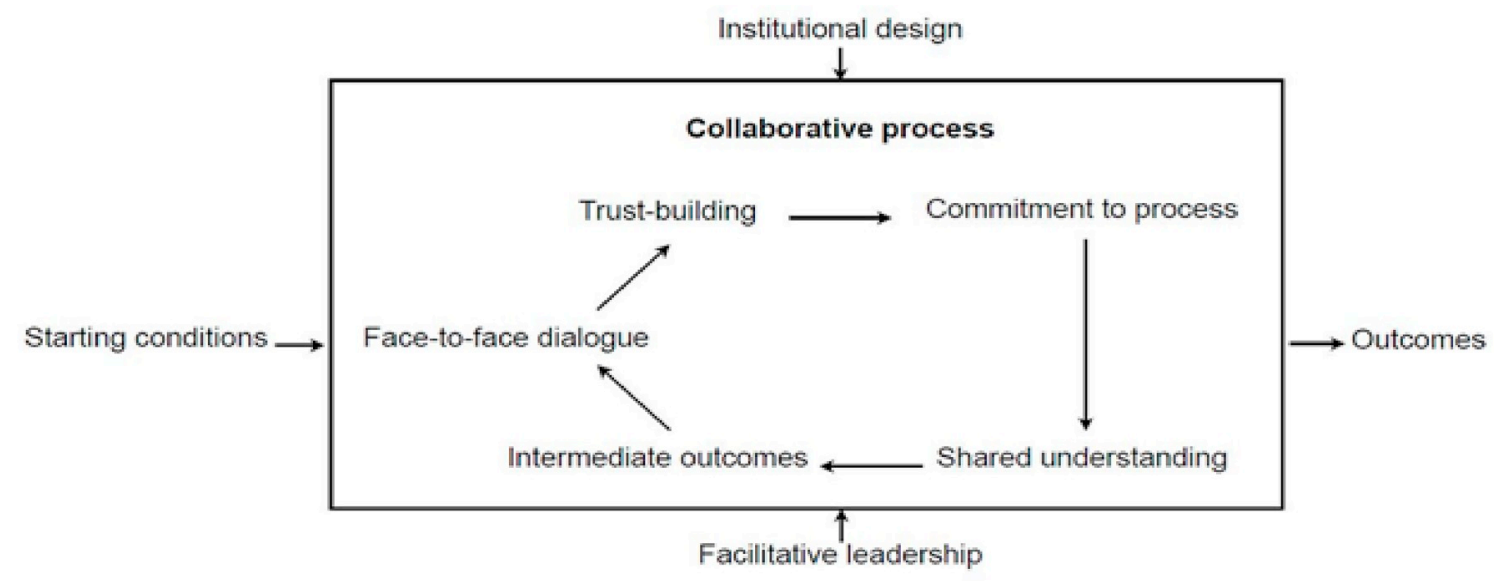

Fig. 1. A general model of collaborative governance (Adapted from Ansell and Gash [7] p. 550). 
usually not very well defined, in this article it is explicitly linked to the capacity to mobilise collaborative action and manage resources.

Fourth, collaborative processes form the basis of a cyclical process of social interactions that can express positive or negative dynamics [19]. Collaborative processes include general communication, trust building, commitment, and shared understanding. These social processes need to be positively reinforced via intermediate outcomes or 'small wins' [28]. Ansell and Gash [7] found that a virtuous cycle of collaboration tends to develop when collaborative forums focus on small wins that deepen trust, commitment, and shared understanding. When conflict levels are high, the need for a combination of small wins and face-to-face dialogue is especially pertinent [8].

\subsection{Case study description}

Bigi Pan is a Multiple Use Management Area (MUMA, IUCN category VI), established in 1987, encompasses an area of 67,900 ha (Fig. 2), and is located in the district of Nickerie. It contains high biodiversity, and is of socio-economic, ecological and ornithological importance [29, 46]. The area consists of a large open water lagoon surrounded by mangrove forest, shallow salt to brackish water, vegetation of short salt plants and salt marsh grasses, and rice fields. Bigi Pan is known for its rich fishery, sedentary coastal birds, and is an important habitat for numerous migratory shorebird species across the Americas [29, 46]. Bigi Pan is designated as a Western Hemisphere Shorebird Reserve Network
(WHSRN) site since 1989 and it supports more than 500,000 shorebirds annually.

Management of Bigi Pan is entrusted to the Head of the Suriname Forest Service (LBB by its Dutch acronym) and daily management is entrusted to the coordinator of the Nature Conservation Division (NCD) within LBB. The main local institutions of Bigi Pan include the NCD Nickerie, the District Commissioner (DC) of Nickerie, the Police, the Department of the Ministry of Agriculture, Animal Husbandry and Fisheries (LVV) and the Department of the Ministry of Public Works, Transport and Communication (OWT\&C) [46]

The MUMA is an area with a special form of management that deserves particular protection by or due to government policy. Several human activities such as agriculture and fisheries can be developed and implemented in such an area, as long as productivity and resources are not exhausted, and yields remain guaranteed. The proposed strategy for fishery focuses on sustainable fishery development which preserves the ecological significance of the natural resources and guarantees sustainable employment and income (White paper "Volume 1: Subsector Fishery 2012-2016", Fishery Management Plan for Suriname 2014-2018). To protect the ecological functions of the estuarine areas, guidelines were established for land allocation regarding these areas (Ministerial decree "Richtlijnen Gronduitgifte Estuariene Beheersgebied 2005" [43]). Consequently, the different land uses for which land can be allocated in the MUMA are limited and advise from the Head of LBB prior to land allocation is a formal requirement.
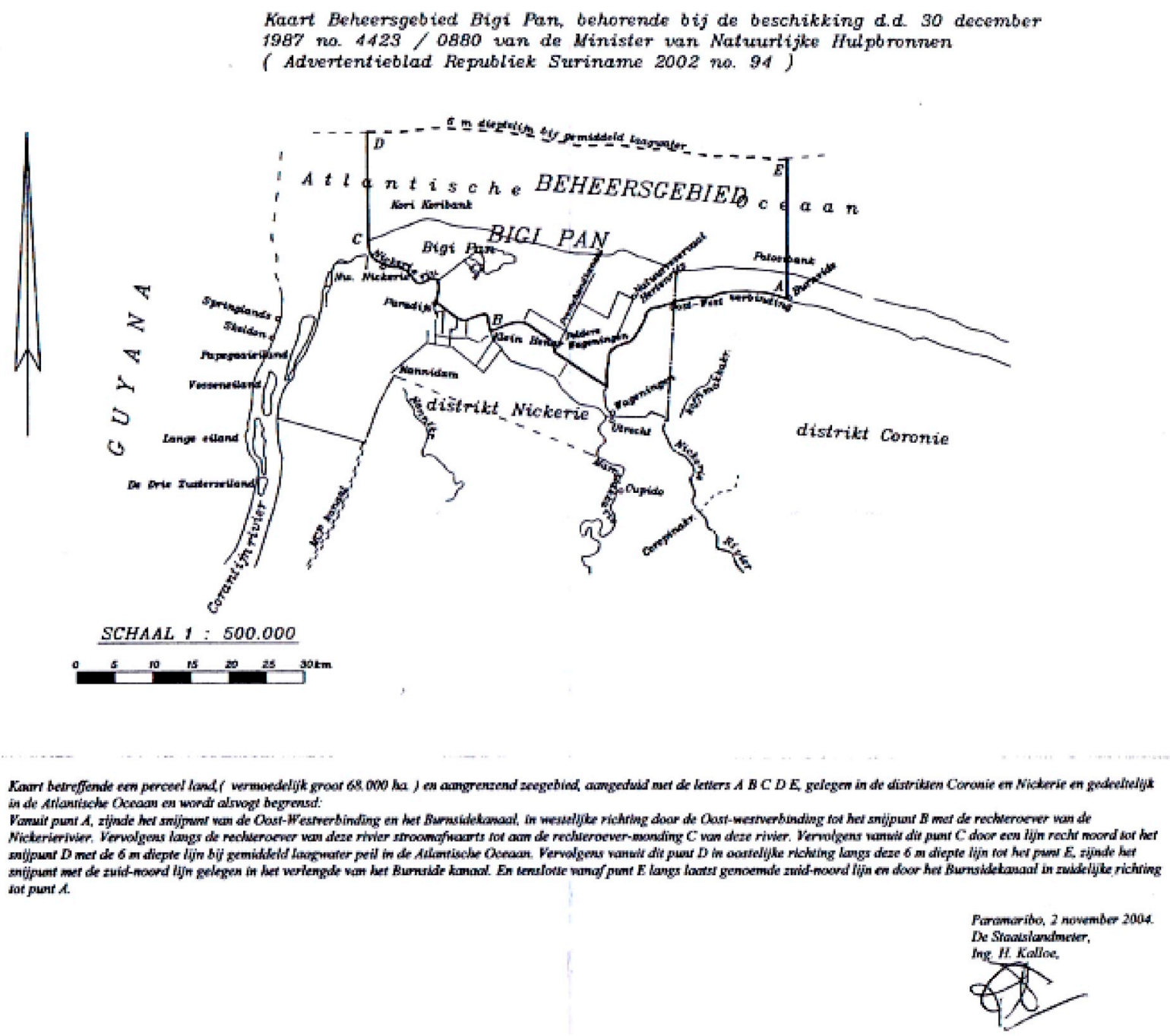

Fig. 2. Map of the Bigi Pan MUMA (Official gazette of the Republic of Suriname). 
The first management plan for the Bigi Pan MUMA was developed in 1990 [42] and it was updated in 1995. Under the Suriname Coastal Protected Area Management project [30] there was another update attempted in 2013, but it was not completed because of disagreements between LBB and the team of consultants about the role of different stakeholders in the management of the MUMA. As a consequence, activities for the Bigi Pan MUMA have not been guided by a management plan in recent years. Currently, the Ministry of RGB is in the process of revising the draft management plan of 2013 and the aim is to have a management approved in 2019 for a period of five years. According to Suriname's National Development Plan 2017-2021 [45] strategy, action and financial plans regarding protected areas of Suriname need to include the strengthening of regulatory and supervisory institutions and the involvement of the local community.

Local communities around Bigi Pan consist of many different ethnic groups that have their own mother tongue. However, Suriname was a former colony of the Netherlands, therefore the official language in Suriname is Dutch. In addition, there is a lingua franca, which almost all Surinamese people are able to speak. This language is Sranang or Surinamese. The main livelihoods of local communities using the MUMA include fishing, fish processing, hunting, tourism and rice farming. Commercial fishing dates back to over 70 years and is carried out in the fishing areas in the MUMA (Fig. 3) and on the coast (Bigi Pan Management Plan 1990). The hunting pressure before 2006 was substantial and resulted in the near complete disappearance of the Jabiru (Jabiru mycteria, a large stork) in the coastal area of Suriname [31]. At the same time, the number of tourists visiting Bigi Pan has been increasing over the last five years. Before, most tourists came for bird watching, while now tourists are engaged in various attractions such as mud baths, kayaking, and wildlife spotting. Demand for smoked fish has been increasing and mangrove forest is being used to smoke fish. All resource users and most visitors of Bigi Pan MUMA engage in fishing activities using small fishing nets. The MUMA includes agricultural areas which covers around $70 \%$ of the land area. Large-scale cultivation of rice is present in the MUMA and surroundings and dates back to more than 70 years (Bigi Pan Management Plan 1990). Fig. 3 below shows a detailed land use map elaborated by the first author.

\subsection{Data collection and analysis}

In July and August of 2017, four weeks of field work were undertaken to study the conditions for collaborative governance. Three qualitative methods for data collection were used: interviews, participant observation, and document analysis. Table 1 gives an overview of the interviewed stakeholders, the sector they represent and their role or practice in the MUMA. Stakeholders included the various governmental agencies that have a responsibility within the MUMA, the resource user groups, and local NGOs. Other actors that have an interest in the Bigi Pan MUMA are considered "indirect" stakeholders. All interviewed stakeholders reported in this study have given explicit and written consent and respondents are kept anonymous.

Twenty-four semi-structured interviews were part of the data collection. Most of the interviewees were selected based on their long history in the MUMA in combination with their frequent presence. The interviews consisted of structured and in-depth interview components and lasted an average of one hour. Different languages (Dutch, Sranang,

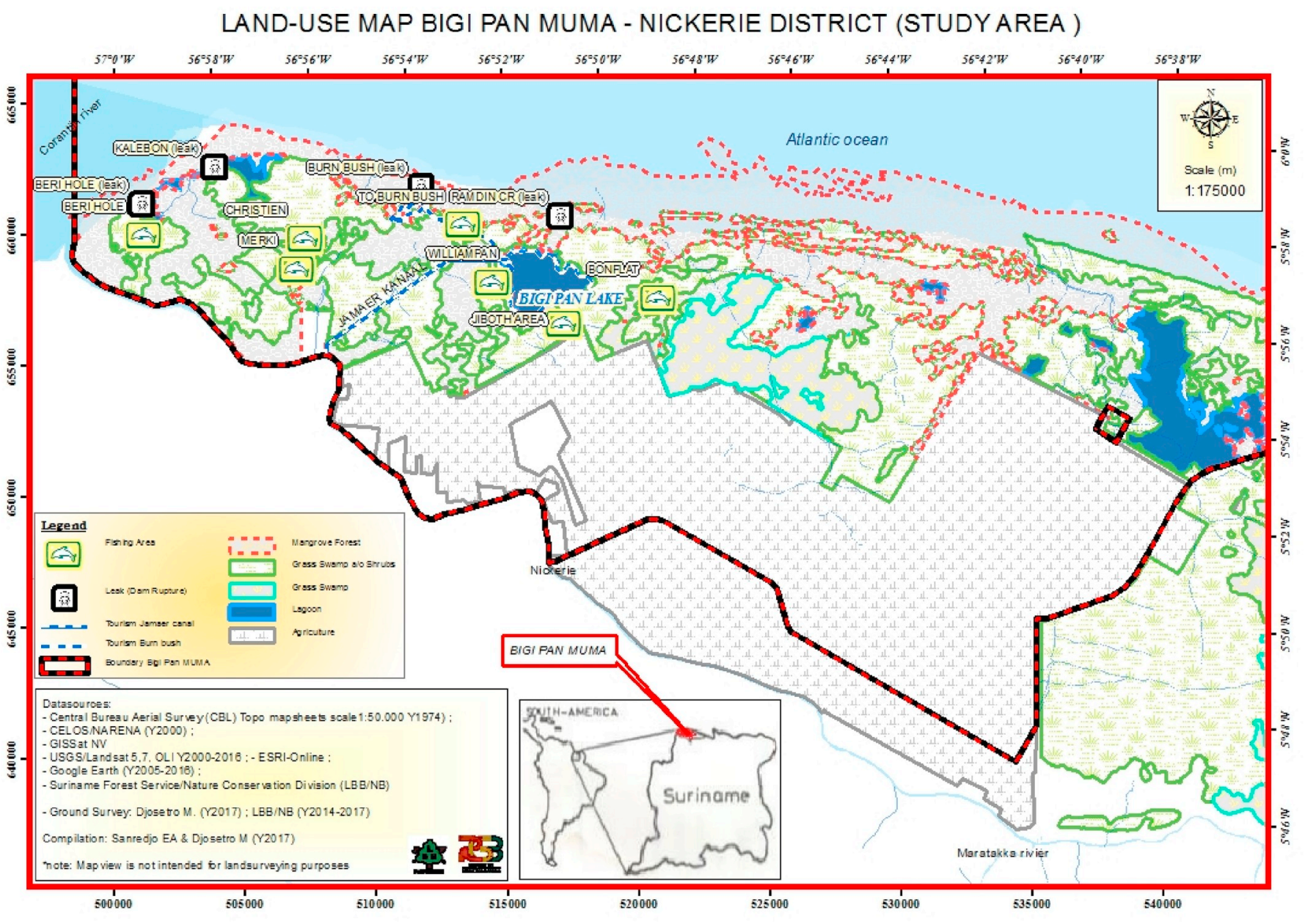

Fig. 3. Land-use map of the Bigi Pan MUMA, situated in Nickerie District. 
Table 1

Overview of interviewed stakeholders.

\begin{tabular}{|c|c|c|}
\hline Sector & Stakeholder & $\begin{array}{l}\text { Role/practice in Bigi Pan } \\
\text { MUMA }\end{array}$ \\
\hline \multirow[t]{6}{*}{ Government } & $\begin{array}{l}\text { Ministry of Physical Planning, } \\
\text { Land and Forest Management, } \\
\text { Nature Conservation Division } \\
\text { (local NCD and head office NCD) }\end{array}$ & $\begin{array}{l}\text { Official management } \\
\text { authority of the MUMA }\end{array}$ \\
\hline & Local Police & Joint patrol team \\
\hline & $\begin{array}{l}\text { Ministry of Regional } \\
\text { Development (local office) }\end{array}$ & $\begin{array}{l}\text { Districts commissariat is head } \\
\text { of the local government }\end{array}$ \\
\hline & $\begin{array}{l}\text { Ministry of Agriculture, Animal } \\
\text { Husbandry and Fisheries (LVV) } \\
\text { (local \& head office) }\end{array}$ & Monitoring fisheries (used to) \\
\hline & $\begin{array}{l}\text { Ministry of Public Works, } \\
\text { Transport and Communication } \\
\text { (OWT\&C) (local office) }\end{array}$ & $\begin{array}{l}\text { Maintenance of } \\
\text { infrastructural works } \\
\text { including canals, sluices and } \\
\text { dikes. }\end{array}$ \\
\hline & Ministry of Defence (local office) & $\begin{array}{l}\text { Fishing project in the context } \\
\text { of their self-sustaining policy }\end{array}$ \\
\hline \multirow[t]{2}{*}{ NGO } & SOLOM & $\begin{array}{l}\text { Support tourism and } \\
\text { awareness raising activities in } \\
\text { Bigi Pan MUMA }\end{array}$ \\
\hline & Local nature conservation NGO & $\begin{array}{l}\text { Support nature conservation } \\
\text { including Bigi Pan MUMA }\end{array}$ \\
\hline \multirow[t]{5}{*}{$\begin{array}{l}\text { Local } \\
\text { resource } \\
\text { users }\end{array}$} & Rice farmers & $\begin{array}{l}\text { Owner of agricultural land in } \\
\text { MUMA for the production of } \\
\text { rice }\end{array}$ \\
\hline & Fish processors in Resort Zeedijk & $\begin{array}{l}\text { Use mangrove branches for } \\
\text { smoking fish }\end{array}$ \\
\hline & Hunters & Mostly hunt on coastal birds \\
\hline & $\begin{array}{l}\text { Lodge holders in MUMA and tour } \\
\text { guides }\end{array}$ & $\begin{array}{l}\text { Provide accommodation to } \\
\text { tourists }\end{array}$ \\
\hline & Fishermen & Fishery as livelihood \\
\hline \multirow[t]{2}{*}{ Scientists } & $\begin{array}{l}\text { Foreign Shorebird researcher } \\
\mathrm{PhD}\end{array}$ & Shorebird research project \\
\hline & $\begin{array}{l}\text { Professor Climate Change \& } \\
\text { Water, Anton de Kom University } \\
\text { of Suriname }\end{array}$ & $\begin{array}{l}\text { Sediment Trapping Unit } \\
\text { research project }\end{array}$ \\
\hline
\end{tabular}

English, and Javanese) were used as not all the interviewees spoke Dutch. An information workshop was organized to inform the interviewed stakeholders about the findings of this study and to request feedback. The interviews were all transcribed to assist analysis.

In addition to the interviews, the first author of this article joined a two-day tourism tour to Bigi Pan MUMA for participant observation. Participant observation was also performed by joining the local NCD for five days for monitoring and enforcement of the Game Act [32] and the Hunting Decree [33]. A day trip was undertaken via the sea with the Hydraulic Division of the Ministry of Public Works, Transport and Communication (OWT\&C) and the local NCD for the monitoring of the constructed dike built at Burn Bush. Furthermore, various policies and regulations regarding the management of the Bigi Pan MUMA were mapped and a literature review was conducted on conservation governance, collaborative governance, policy implementation and resource conflict. Finally, existing documentation on resource utilization and resource users of the MUMA was collected and analyzed.

Data analysis took place throughout the research process. All data, including interview transcripts and documents, were analyzed using qualitative data analysis software (Atlas-ti). A mix of open and deductive coding was used. Open coding allowed major themes in conservation governance to occur. Deductive coding ensured relevant data related to the analytical framework of collaborative governance.

\section{Results}

Below, the conditions of collaborative governance and its variables are presented as they have occurred in the Bigi Pan MUMA. Table 2 summarizes the results and offers an assessment of the conditions of the collaborative governance in the Bigi Pan MUMA and their respective social elements. The contents of the table are discussed in detail in the
Table 2

An assessment of the conditions of the collaborative governance in the Bigi Pan MUMA and their respective social elements. The color code refers to the extent to which the elements are present: green - positive presence (not found in any condition); yellow - moderate level; red - absence or negative presence.

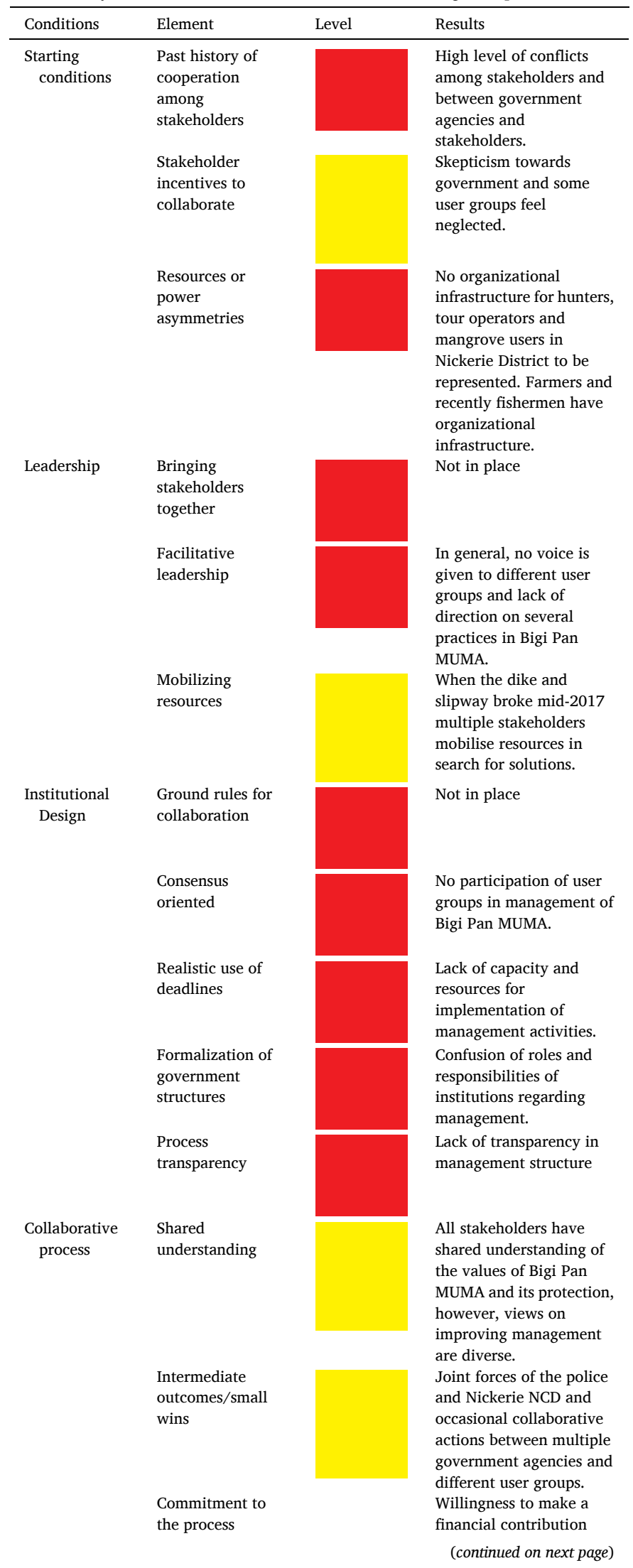


Table 2 (continued)

\begin{tabular}{|c|c|c|c|}
\hline Conditions & Element & Level & Results \\
\hline & & & $\begin{array}{l}\text { based on statutory } \\
\text { regulations. }\end{array}$ \\
\hline & $\begin{array}{l}\text { Face-to-Face } \\
\text { dialogue }\end{array}$ & & $\begin{array}{l}\text { Communication between } \\
\text { government agencies and } \\
\text { different user groups only } \\
\text { recent }\end{array}$ \\
\hline
\end{tabular}

next four subsections.

\subsection{Starting conditions}

Multiple conflicts over resource use in the MUMA complicated starting conditions for collaborative governance. First, dried mangrove branches had always been collected by the fish processors of resort Zeedijk to smoke fish. Recent increasing demand for smoked fish had led to an increased collecting of not only dried mangrove branches, but also of green branches. Dry mangrove branches were also used as firewood for cooking by the various users of Bigi Pan, but the frequency and quantity of the harvest for this purpose was small compared to the use of branches for fish processing. Moreover, the function of the mangrove as a natural habitat and as natural coastal protection was threatened by overexploitation.

Second, the capture of bird species was a matter of concern. Official reports showed many cases in which people violated the law and captured bird species during the closed hunting season. Interviews with hunters revealed that there was an inconsistency in handling the different offenders where some offenders paid a fine while others did not. From some offenders the shotgun was confiscated while others were allowed to keep their weapons. This created conflict situations and undermined trust in the management of Bigi Pan MUMA. Interviewees also reported that some of the game wardens of the Nickerie NCD tipped off their friends when enforcement activities were planned for the Bigi Pan MUMA. Moreover, hunters who did not comply with the rules were not only Surinamese, but also hunters with the Guyanese nationality. Finally, hunters got competition from fishermen who were also hunting while fishing in the MUMA.

"People say that the Bigi Pan MUMA is a protected area, but there are many poachers, Guyanese people and our own people shoot at the protected bird species". (Interviewee \#1)

Third, tourism was putting increasing pressure on local resources. At the time of research, Bigi Pan had three lodges for tourists and on average 25 people could stay in one lodge. During the high season, June to the end of September, these lodges are fully booked. Some of the interviewees expressed concern about the attitude and behavior of tourists with regard to waste and sanitation. Urine and feces are disposed untreated into the water of Bigi Pan. In the past, only tour operators brought tourists to Bigi Pan, but nowadays fishermen and hunters also act as tourist guides. These tourism activities have not been monitored at all which created discontent. Conflicts thus arose regarding waste management, with fishermen and tour operators accusing each other of bad practice. Another conflict was about fishing by the tour operators and tourists: non-residents want to eat fish and residents want to take fish home. Conflict also arose when a non-local individual received a permit to build a large lodge in the Bigi Pan MUMA mid-2017.

A fourth conflict concerned competition among fishermen for the few fishing areas which are deeper and where fish stocks are concentrated. Fishermen reported that the average size of the fish became smaller over the years. Some fishing areas that used to have a lot of fish were recently densely overgrown with grass and the fish population has become depleted [30]. Fishermen who have a fish license believe that not all persons entering the Bigi Pan MUMA should be allowed to fish without restrictions. According to one young fisherman, his income was reduced because lodge holders and visitors are not buying his fish anymore and now fish themselves. Therefore, fishermen also took on hunting and tourism activities.

Incentives for fishermen to collaborate with government and other stakeholders were mostly lacking. Rules were not clear regarding monitoring of fishing and even for the local governmental agencies it was not clear who is responsible for this. Enforcement of the Fish Stock Protection act [34] is partly done by the NCD Nickerie which created confusion among fishermen. They expected the local Fisheries Service to control fishermen and not the NCD Nickerie. Interviews revealed a lack of trust in the management of Bigi Pan and in a recently established fish cooperation. Another issue was the allowance of use of fyke nets which was unclear to some fishermen:

"I don't agree when the Nickerie NCD bothers fishermen who are putting fyke nets more than a kilometer distance from the coast". (Interviewee \#2)

Using fyke nets happens at spring flood when fishing is good and many fish come along with the water that flows into Bigi Pan.

Incentives for collaboration were also low with farmers. Rice farmers have been facing problems with flooding for many years and this problem had been brought to the attention of the government many times, however it still remained unsolved. Rice farmers pointed out a lack of dialogue between them and the government and felt neglected:

"LVV really does nothing to solve the flooding problem and does not stimulate us. Farmers have a lot of complaints about the water problem, but no solution has been given". (Interviewee \#3)

Organizational and power imbalances between resource users were also present in the MUMA. While the fishermen organized themselves only recently, the rice farmers have been organized for a much longer time. There is no organizational infrastructure for hunters, tour operators, and other mangrove users that are present in the Nickerie District. A negotiation table between the various stakeholders did not exist during the research period and governmental stakeholders reported difficulties to engage user groups in collaborative processes. While governmental stakeholders held the power to give fines and exercise some control over resource use practices, the other stakeholders felt they have little influence on resource management.

\subsection{Institutional design}

Ground rules for collaboration between governmental agencies and communities were not in place, even when multiple interviewees indicated a wish to be involved. There was also a lack of transparency in management structures. Consensus between different user groups was also not formally strived for and was likely only reached among governmental agencies regarding law enforcement, as there was no participation of the user groups in management.

The Game Act [32] and the Hunting Decree [33] provide guidance for hunting activities. They indicate when a particular game can be hunted during the calendar year. The Fish Stock Protection Act [34]; modified in 1981) gives direction to fisheries management, the determination of the minimal size of fish to be caught and the fishing season. The Head of the Suriname Forest Service is a management authority for the MUMA but it is the LVV Fisheries Department that issues fish licenses. Without a fish license one is not allowed to fish in Bigi Pan with nets. Fishing rod and a line with a hook attached are permitted for people without a fish license [34]. Although government structures are formalized there was confusion about roles and responsibilities of government agencies regarding fishery in the MUMA. There were no 
regulations with clear provisions regarding other resource uses in Bigi Pan MUMA. Regulations for the tourism industry in Bigi Pan were not in place while according to some respondents Bigi Pan has been becoming more and more a tourist place as visitor numbers increase.

Economic, informative and regulatory policy instruments were not deployed due to capacity constraints such as a lack of qualified personnel and finances. These constraints resulted in an implementation gap regarding awareness, monitoring, and enforcement. Implementation of management activities via deadlines was moreover missing. The Nickerie NCD had received funding for bird conservation which created the possibility to guide law enforcement regarding hunting activities on migratory birds and Scarlet ibises in the MUMA. However, there were no funds for law enforcement regarding other coastal birds.

Process transparency was relatively low, notwithstanding attempts to change this. The first management plan for the Bigi Pan MUMA was developed in 1990, afterwards there were updates in 1995 and the last update was in 2013. However, at the time of this research, the Ministry of RGB had not approved this update due to areas of disagreements over the role of the different relevant stakeholders in the management of the MUMA. Moreover, the Coordinator of the NCD indicated that MUMAs have no strong legal basis compared to other protected areas, which have stronger laws and regulations as basis. There are no specific provisions in the law and regulation to effectively protect Bigi Pan (personal communication 2017). She further explained that the information of the carrying capacity of the resource system for every practice in Bigi Pan is necessary to inform policy making, this information was missing at the time of research.

\subsection{Leadership}

Both resource users and the local government agencies viewed the management of Bigi Pan MUMA as poor and chaotic. Local government agencies lacked the capacity and resources to carry out management activities such as monitoring and enforcement for various resource uses. These agencies were dependent on a centralized financial budget. Most respondents expressed concern about the lack of monitoring regarding people and products entering or leaving the MUMA. Moreover, a lack of understanding of ecosystem interactions also contributed to a lack of collaborative action according to a professor of the Anton de Kom University of Suriname:

"People know that mangrove forest is important but have no insight into what this means". (Interviewee \#4)

Some of the respondents believed that improved management of the MUMA can be achieved through collaboration when all stakeholders act according to their duties and responsibilities. They further argued that resource users also should have a role in the management as they know the Bigi Pan area well. Although the Fisheries Department also supported collaborative action regarding management, they argued that Bigi Pan being a MUMA and the NCD being the management authority, the latter should be doing the general monitoring including the fish stock monitoring. If the NCD needs capacity building to do the fish stock monitoring, the Fisheries Department suggested they would come in with training.

The lack of an organizational infrastructure of the hunters, tour operators and mangrove users in Nickerie District made it difficult for local user groups to adequately give voice to their interests and concerns. Therefore, they held a disadvantage compared to the rice farmers and fishermen who had organized themselves. According to a member of the fish cooperation the local government talked only with representatives of fishermen and not to individuals:

"The District Commissioner and the Police do not want to talk with individuals but want to work with a group of people in a team". (Interviewee \#5)
This was the reason the fishermen recently created an organizational infrastructure through the establishment of a fishery cooperation.

At times, stakeholders were successful in working together and mobilizing resources together, for example when the dike and the slipway broke mid-2017. The various governmental agencies lacked resources for work in the field, but with the intervention of the user groups it was possible for them to do an orientation survey. The tour operators and fishermen provided transportation and when necessary the tour operator provided accommodations in the MUMA for free. The multiple stakeholders thus showed leadership by mobilizing resources collectively. Government agencies also collaborated during this incident: the Ministry of OWT\&C and the Nickerie NCD visited the Bigi Pan MUMA together via the sea to monitor the recently constructed dike by a contractor at Burn Bush.

Apart from this monitoring of the dike, local leadership on other issues in the MUMA, such as strategic planning for tourism and fisheries, was mostly absent. Local stakeholders and government agencies likely perceived such issues less urgent to solve and were waiting for the central government to solve issues such as pollution and overexploitation of resources. While the NCD Nickerie was willing to facilitate stakeholder engagement, at the time of research it did not have the capacity and resources to do so. It was clear that in an alarming event like that of the dam break, cooperation was possible and did happen. However, the processes of 'bringing stakeholder together' and 'mobilizing resources' did not take place more structurally.

\subsection{Collaborative process}

Results showed a certain shared understanding of stakeholders with regard to the importance and values of Bigi Pan MUMA. The MUMA is valued by the local community of Nickerie District, other Districts of Suriname, the neighboring country Guyana, and is considered of global importance for the conservation of coastal and migratory birds and is recognized for a high diversity of coastal birds such as Scarlet Ibis and Flamingo's [35]. Bigi Pan is suitable for bird watching, training, research, and education purposes. The area acts a buffer between the sea and coastal plain. Farmers benefit from this buffer because the salt sea water does not reach the rice fields. According to one fisherman, all Suriname's youth in general and the Nickerie youth in particular, should visit Bigi Pan to learn about the amazing birds, to admire the beautiful nature, and to enjoy and to relax.

Collaborative processes built on a number of intermediate outcomes (or small wins). The event of the dike and slipway break mid-2017 had helped support a new expression of the intent to collaborate by various stakeholders and users. There was a mutual recognition of interdependence among the Nickerie NCD and the local police with regard to law enforcement of hunting activities. The NCD Nickerie tried to manage Bigi Pan by working with the DC of Nickerie and the local police. According to the Coordinator of the NCD, the DC of Nickerie played an important role in the management of Bigi Pan and had a good working relation with the NCD Nickerie. When somebody tipped the NCD Nickerie that illegal activities were taking place in Bigi Pan, the NCD Nickerie and police joined forces to take action.

The various stakeholders have come to realize that they could not achieve their common goal of conservation of the Bigi Pan MUMA without engaging in a collaborative process with each other. They showed broad support for an entrance fee for visitors and/or toll for products of nature such as fish and birds. Interviewees argued that the collected money can be used to retain the MUMA: maintenance, management and monitoring activities. All resource users showed willingness to make a financial contribution but argued that first a statutory regulation should be in place. In 2000, there was a pilot project for the collection of fees to create a fund for Bigi Pan MUMA, but this project failed due to lack of statutory regulations. Therefore, statutory regulations should be developed for stakeholders to commit to this arrangement. 
In general, there was no communication among government agencies nor with the user groups on a regular basis. More communication only recently started taking place. In addition, the position of the government regarding monitoring of fishing activities remained unclear due to a lack of communication between both agencies. Communication and transparency were revealed by the stakeholder interviews to be important for this collaborative process between various stakeholders. Some interviewees pointed out that awareness about the conservation of Bigi Pan by the different resource users is needed, including the tourists who could potentially make a substantial contribution to nature conservation. Those who claimed to understand the function and importance of the conservation of Bigi Pan did follow the rules, but likely represented a small group of the resource users.

\section{Discussion}

\subsection{Conflict, user pressure, and implementation gaps}

Resource conflicts in Bigi Pan result from increased competition for the natural resources in the MUMA, a lack of resources, a lack of clarity about enforcement and monitoring activities regarding fishery, and a lack of regulations for other activities. 'Poor governance' [36] in terms of a lack of leadership and of a functioning institutional framework is thus a key obstacle to overcome these conflicts. As a way out, the Coordinator of NCD (personal communication 2017) currently proposes that government agencies and non-state stakeholders engage collaboratively to develop a new legislation for the protection of Bigi Pan MUMA in general. This could theoretically lead to a better understanding of the importance of protecting the mangrove forest within the local community and for example lead to the acceptance of a ban or restrictions on harvesting branches of the mangrove forest. Following the model of collaborative governance, such a strategy to strengthen institutions and engagement with stakeholders should be accompanied by a focus on facilitative leadership, the realization of small wins, and strategies to overcomes power imbalances and to include all user groups [37].

Overcoming conflicts and user pressures is deemed not possible without also strengthening management capacity [13]. The local NCD in the Nickerie District lacks the basic management needs for monitoring work, such as fuel for cars and boats. The resulting failure to act leads to frustration with staff and also contributes to a negative image of the NCD fining some transgressors but not others. Another impact is that undesired behavior will not be corrected, with the possibility that other people copy this behavior. On the long-term, costs thus increase for conservation. Moreover, social interactions are likely to remain stuck in conflict dynamics [21]. While Game Wardens are dedicated to the conservation work, they often carry out multiple tasks when on mission due the lack of staff. High work pressure is a result, and this has a negative impact on their well-being. Thus, the will and ability to facilitate stakeholder engagement and carry out monitoring is hampered by costs and other operational limitations [1].

We found many similarities between the challenges to resource management in the Bigi Pan MUMA and similar MPAs located in Central America and the Caribbean. Capacity for coastal resource management is considered weak across the region [22,38]. In cases where management of MPAs is strong, the effectiveness of fines and penalties in governance has been reported to be moderately successful [39]. However, other governance mechanisms are necessary as well. In the case of the Bigi Pan MUMA, there is no regulation in place for the tourism industry and it is unclear who is responsible for monitoring fishing activities. As the management of the MUMA is still government-led and the opinion of the local community was not take much into consideration in the past, calls for stronger inclusion of communities still need to be followed-up in Suriname more convincingly [23].

\subsection{Collaborative action}

The value of Bigi Pan MUMA remains a focus for the multiple stakeholders and can be considered an important positive condition for collaborative action. According to Ansell and Gash [7]; a high level of conflict may actually create a powerful incentive for collaborative governance, if interdependency among stakeholders is highly present, whereby positive steps should be taken to remediate the low levels of trust and social capital among the stakeholders [7]. The information workshop held with stakeholders as part of this research to reflect on preliminary results of this study revealed that stakeholders clearly understand that if no actions will be taken and management is not improved, the natural sanctuary of Bigi Pan will likely disappear in less than fifty years in terms of biodiversity loss as well as land loss because of coastal erosion. It appears that this shared understanding has recently led to some collaborative action, where leadership comes both from the community represented by the user groups and the local governmental agencies. This small win from collaborative actions may potentially propel the iterative cycle of the collaborative process forward [7,28].

Even with positive collaborative dynamics, a structural lack of resources and ability to execute management actions represents an implementation gap [36] in which conflicts among resource users over natural resources will likely remain and/or return. The collaborative actions between stakeholders are seen positively and stakeholders argue that this can be an example of how other MUMAs in Suriname can be managed. Still, some stakeholders argue that laws need to be better enforced for Bigi Pan to serve as an example for others. That is why monitoring of activities such as hunting and sport fishing are important. Research indeed shows that high fines - if consistent and combined with regularly monitoring of activities in the MUMA - can have a positive effect on the behavioural change of the local communities and therefore also on marine and bird ecology [39].

The importance of collaboration between states and non-state actors and of community leadership has been shown for multiple cases in the Caribbean region [40]. In Suriname, these ideas have recently been incorporated in the National Development Plan 2017-2021. As a result, the development of management plans for all protected areas, including the Bigi Pan MUMA, is required to include participatory processes. Accordingly, a challenge is to create a stakeholder organisation for the management of natural resources with both the necessary management capacity and the support and endorsement of central government and political leaders. Moreover, local capacity to deal with various opinions and interests and community leadership will play a crucial role in developing a common goal.

\subsection{Methodological limitations}

A challenge during data collection was the diverse make-up of the population of Suriname, particularly in the coastal areas, which consists of different ethnic groups that each has its own culture and tradition. The different languages that people speak sometimes made it difficult to translate into English while respecting local context. Sometimes it was moreover necessary to repeat the collected information for validation, which made interviews lengthier on average. There is also not much documentation about the coast of Suriname, particularly from the perspective of collaborative governance. The availability of written documents was therefore often limited to government documents. The many government agencies involved in the management of the MUMA have made this more complex.

Data collection was structured to follow the analytical categories set out by Ostrom [4] on natural resource systems - e.g. the governance structure, different uses of the natural resources and the user groups while the data analysis followed the model of Ansell and Gash [7]. Based on the variables that belong to the key conditions, the coding took place and contributed to investigate whether sustainable management of the natural resources within the MUMA has taken place. We found that the 
relevance of both models is that they emphasize local context on the basis of which governance choices and management actions should take place.

\section{Conclusion}

The results of this study suggest that whether collaborative processes will occur in the future depends on the present conditions of the natural resource governance. Shared understanding of the need to protect natural resources in the Bigi Pan MUMA among stakeholders, the need for law enforcement to address hunting activities, and the need for increased management and monitoring capacity may bring about a collaborative process. According to Ostrom [4]; long-term sustainability moreover depends on how well rules match the local context; on communities not being overruled by larger government policies; and on users' willingness to monitor one another's harvesting practices. Indeed, community leadership has been shown to be a success factor for sustainable management of many MPAs in the Caribbean region [40]. Even so, continued anthropogenic pressures on natural resources will start to compromise the sustainable performance of the MUMA unless investment in human and financial capacity of government agencies to monitor is also increased [16]. The capacity and resources of government agencies to communicate with stakeholders and to execute policies effectively are other key issues. The case of Bigi Pan strongly points to the need for involvement of resource users in the management and monitoring of the MUMA [12] and the importance of communication for the solution of several issues [37].

In conclusion, local communities have the potential to address conflicts, user pressure, and implementation gaps which lead to unsustainable practices in the Bigi Pan MUMA, but an 'easy fix' does not exist. The collaborative governance model in particular makes clear that human dimensions of conservation strongly matter and have considerable influence on conservation outcomes [1]. Institutional innovations such as participatory drafting of management plans may offer a way to bridge the lifeworld of local communities and globally embraced conservation goals. This is also a conclusion that McConney and Pomeroy [41] make, who argue that the creation of new stakeholder organizations and/or the strengthening existing organizations can help overcome management challenges in Central America and the Caribbean. Furthermore, organizational arrangements should focus on the development of rules that are sensitive to local context and that include active management and monitoring. Any institutional innovation for marine protected areas - including the Bigi Pan MUMA - needs to draw both on local leadership and on a shared understanding of the need to conserve natural resources. We believe this requires open dialogues that include local users, government agencies, as well as other actors who take an interest.

\section{Funding}

This work was supported by the Nature Conservation Division of the Suriname Forest Service with partly funding by the GCCA project.

\section{Acknowledgements}

The authors would like to thank Sakimin C., the staff of the Nature Conservation Division of the Suriname Forest Service, Sanredjo E.A., Drakenstein B. and Blom C. for their support. We are also grateful to all interviewees for their time and effort to participate in the research.

\section{Appendix A. Supplementary data}

Supplementary data to this article can be found online at https://doi. org/10.1016/j.marpol.2019.103746.

\section{References}

[1] P. Christie, N.J. Bennett, N.J. Gray, T.A. Wilhelm, N. Lewis, J. Parks, N.C. Ban, R. L. Gruby, L. Gordon, J. Day, S. Taei, A.M. Friedlander, Why people matter in ocean governance: incorporating human dimensions into large-scale marine protected areas, Mar. Policy 84 (2017) (2017) 273-284.

[2] N. Jens, F. Oliver, Environmental Governance: Participatory, Multi-Level - and Effective? UFZ Diskussionspapiere, No. 15/2008, 2008. http://hdl.handle.net/10 $419 / 44744$.

[3] A.A. Adenle, C. Stevens, P. Bridgewater, Stakeholder visions for biodiversity conservation in developing countries, Sustainability 2015 (2015) 7.

[4] E. Ostrom, A general framework for analyzing sustainability of social-ecological systems, Science 325 (2009).

[5] J.C. Fernández-Baca, A.S. Martin, Indigenous Peoples and Protected Areas Management. Innovations in Conservation Series, Parks in Peril Program, The Nature Conservancy, Arlington, VA, USA, 2007.

[6] K. Niedziałkowski, J. Paavola, B. Jedrzejewska, Participation and protected areas governance: the impact of changing influence of local authorities on the conservation of the Bialowieza Primeval forest, Poland, Ecol. Soc. 17 (1) (2012) 2.

[7] C. Ansell, A. Gash, Collaborative governance in theory and practice, Oxford University Press, 2007 on behalf of the Journal of Public Administration Research and Theory, Inc. All rights reserved.

[8] K. Emerson, T. Nabatchi, S. Balogh, An integrative framework for collaborative governance, Oxford University Press, 2011 on behalf of the Journal of Public Administration Research and Theory, Inc. All rights reserved.

[9] N.J. Bennett, P. Dearden, Why local people do not support conservation: community perceptions of marine protected area livelihood impacts, governance and management in Thailand, Elsevier 44 (2014) (2014) 107-116. Marine Policy.

[10] N.C. Ban, M. Mills, J. Tam, C.C. Hicks, S. Klain, N. Stoeckl, M.C. Bottrill, J. Levine, R.L. Pressey, T. Satterfield, K.M. Chan, A social-ecological approach to conservation planning: embedding social considerations, Front. Ecol. Environ. 11 (4) (2013) 194-202.

[11] K. Bosak, Nature, conflict and biodiversity conservation in the Nanda Devi biosphere Reserve, Conserv. Soc. 6 (3) (2008) 211-224.

[12] J. Bluwstein, F. Moyo, R.P. Kicheleri, Austere conservation: understanding conflicts over resource governance in Tanzanian wildlife management areas, Conserv. Soc. 14 (3) (2016) 218-231.

[13] I. Álvarez-Fernández, N. Fernández, N. Sánchez-Carnero, J. Freire, The management performance of marine protected areas in the North-east Atlantic Ocean, Mar. Policy 76 (2017) (2017) 159-168.

[14] A. Arias, J.E. Cinner, R.E. Jones, R.L. Pressey, Levels and drivers of Fishers' compliance with marine protected areas, Ecol. Soc. 20 (4) (2015) 19.

[15] D. Pauly, V. Christensen, S. Guenette, T.J. Pitcher, U.R. Sumaila, C.J. Walters, R. Watson, D. Zeller, Towards sustainability in world fisheries, Nature 418 (2002) 689-695.

[16] D.A. Gill, M.B. Mascia, G.N. Ahmadia, L. Glew, S.E. Lester, M. Barnes, I. Craigie, E. S. Darling, C.M. Free, J. Geldmann, S. Holst, O.P. Jensen, A.T. White, X. Basurto, L. Coad, R.D. Gates, G. Guannel, P.J. Mumby, H. Thomas, S. Whitmee, S. Woodley, H.E. Fox, Capacity shortfalls hinder the performance of marine protected areas globally, Nature 543 (2017).

[17] G.J. Edgar, R.D. Stuart-Smith, T.J. Willis, S. Kininmonth, S.C. Baker, S. Banks, N. S. Barrett, M.A. Becerro, A.T.F. Bernard, J. Berkhout, C.D. Buxton, S.J. Campbell, A.T. Cooper, M. Davey, S.C. Edgar, G. Försterra, D.E. Galván, A.J. Irigoyen, D. J. Kushner, R. Moura, P.E. Parnell, N.T. Shears, G. Soler, E.M.A. Strain, R. J. Thomson, Global conservation outcomes depend on marine protected areas with five key features, Nature 506 (2014).

[18] C. Charlie, B. King, M. Pearlman, The application of environmental governance networks in small island destinations: evidence from Indonesia and the coral triangle, Tour. Plann. Dev. 10 (1) (2013) 17-31.

[19] C.M. Kossmann, J.H. Behagel, M. Bailey, Action and inertia in collaborative governance, Elsevier 72 (2016) (2016) 21-30. Marine Policy.

[20] W. Flannery, N. Healy, M. Luna, Exclusion and non-participation in marine spatial planning, Mar. Policy 88 (2018) 32-40.

[21] M. Van Leeuwen, G. Van Der Haar, Theorizing the land-violent conflict nexus, World Dev. 78 (2016) 94-104.

[22] A. Aguilar-Perera, M. Schärer, M. Valdés-Pizzini, Marine protected areas in Puerto Rico: historical and current perspectives, Ocean Coast Manag. 49 (2006) (2006) 961-975.

[23] M.D.M. Delgado-Serrano, J. Mistry, B. Matzdorf, G. Leclerc, Community-based management of environmental challenges in Latin America and the Caribbean, Ecol. Soc. 22 (1) (2017).

[24] R. Pomeroy, J. Parks, R. Pollnac, T. Campson, E. Genio, C. Marlessy, E. Holle, M. Pido, A. Nissapa, S. Boromthanarat, N. Thu Hue, Fish wars: conflict and collaboration in fisheries management in Southeast Asia, Mar. Policy 31 (2007) (2007) 645-656. Elsevier.

[25] F. Berkes, Community-Based Conservation in a Globalized World, The National Academy of Sciences of the USA, 2007.

[26] M.E. Méndez-López, E. García-Frapolli, D.J. Pritchard, M.C.S. González, I. RuizMallén, L. Porter-Bolland, V. Reyes-Garcia, Local participation in biodiversity conservation initiatives: a comparative analysis of different models in South East Mexico, Environ. Manag. 145 (2014) 321-329. Elsevier.

[27] K.A. Waylen, A. Fisher, P.J.K. McGowan, S.J. Thirgood, E.J. Milner-Gulland, Effect of local cultural context on the success of community-based conservation interventions, Conserv. Biol. ume 24 (No. 4) (2010) 1119-1129. 
[28] C.J.A.M. Termeer, A. Dewulf, A small wins framework to overcome the evaluation paradox of governing wicked problems, Policy Soc. (2018). 10.1080/14494 035.2018.1497933.

[29] O.H. Ottema, Suriname. pp 345-350, in: C. Devenish, D.F. Diaz Fernandez, R. P. Clay, L. Davidson, Yepez Zabala (Eds.), Important Bird Areas Americas - Priority Sites for Biodiversity Conservation, vol. 2009, BirdLife International (BirdLife Conservation Series No. 16), Quito, Ecuador, 2009.

[30] UNDP Suriname, Project Document, Suriname Coastal Protected Area Management, 2011.

[31] A. Spaans, Results Hunting Questionnaire Suriname, 2006.

[32] Game Act, Jachtwet 1954 (G.B. 1954 no. 25 zoals laatstelijk gewijzigd bij S.B. 2002 no. 116, 1954.

[33] Hunting Decree, Jachtbesluit 2002, S.B. 2002 no. 116, 2002.

[34] Fish Stock Protection Act 1961 (Vistandbeschermingswet 1961 (G.B. 1961 no. 44 zoals laatstelijk gewijzigd bij S.B. 1981 no. 66).

[35] A.L. Spaans, O.H. Ottema, J.J.M. Ribot, Fieldguide to the Birds of Suriname, Koninklijke Brill nv, Leiden, The Netherlands, 2016.

[36] G. Borrini-Feyerabend, N. Dudley, T. Jaeger, B. Lassen, N.P. Broome, A. Phillips, T. Sandwith, Best Practices Protected Area Guidelines Series No. 20, Governance of Protected Areas: from Understanding to Action, IUCN, Gland, Switzerland, 2013, p. 124. xvi \pm .

[37] L.R. Larson, A.L. Conway, S.M. Hernandez, J.P. Carroll, Human-wildlife conflict, conservation attitudes, and a potential role for citizen science in Sierra Leone, Africa, Conserv. Soc. 14 (3) (2016) 205-217.
[38] N.P.M. Sevilla, M. Le Bail, Latin American and Caribbean regional perspective on ecosystem based management (EBM) of large marine ecosystems goods and services, Environ. Dev. 22 (2017) 9-17.

[39] K.A. Kaplan, G.N. Ahmadia, H. Fox, L. Glew, E.F. Pomeranz, P. Sullivan, Linking ecological condition to enforcement of marine protected area regulations in the greater Caribbean region, Mar. Policy 62 (2015) 186-195.

[40] S. Chen, D. Ganapin, Polycentric coastal and ocean management in the Caribbean Sea Large Marine Ecosystem: harnessing community-based actions to implement regional frameworks, Environ. Dev. 17 (2016) 264-276.

[41] Technical Report No.5P. McConney, R. Pomeroy (Eds.), Reforming Governance: Coastal Resources Co-management in Central America and the Caribbean. Final Report of the Coastal Resources Project (CORECOMP), CERMES, 2006, p. 63.

[42] Environment Canada, Ministerie van Natuurlijke Hulpbronnen, Bigi Pan bijzonder beheersgebied beheersplan, in: samenwerking met de Ministeries van: Landbouw, Veeteelt en Visserij, Regionale Ontwikkeling, Openbaren Werken en de Stichting Planbureau Suriname, 1990.

[43] Ministerie van Natuurlijke Hulpbronnen, Ministeriële beschikking Richtlijnen Gronduitgifte Estuariene beheersgebied 2005. No. 180/0036, 2005.

[45] Stichting Planbureau Suriname, Ontwikkelings plan 2017-2021, Ontwikkelingsprioriteiten van Suriname, Regering van de Republiek Suriname, 2017.

[46] UNDP Suriname, Draft Bigi Pan management plan 2013-2023, Suriname Coastal Protected Area Management Project, 2013. 